\title{
The Education of Future Immunologists: Lessons from the Doherty Lab
}

\author{
Judith A. Owen
}

Keywords: education, collaboration, communication

$\mathbf{I}_{\mathrm{r}}^{\mathrm{T}}$ T IS A DEEPLY felt privilege to contribute to this volume in honor of Peter Doherty. I was fortunate enough to be a postdoctoral fellow in Peter's laboratory from 1978 to 1981. During that period and under his guidance, I developed the limiting dilution assay for the measurement of influenzaspecific cytotoxic $\mathrm{T}$ cell precursors, which his laboratory used for some time. Eventually, limiting dilution measurements were superseded by the more sensitive, rapid, and convenient tetramer-based assays. Reflecting, as I write this, on the differences between those two methodologies, I find myself wondering whether limiting dilution assays in fact measure the frequency of a discrete developmental $\mathrm{T}$ cell subset within the overall population of $\mathrm{CD}^{+} \mathrm{T}$ cell precursors. Specifically, since limiting dilution technology requires that the cytotoxic $\mathrm{T}$ cell precursors must proliferate extensively to be detected, it is possible that what we were actually measuring was the frequency of central memory $\mathrm{CD}^{+} \mathrm{T}$ cell precursors, a hypothesis that is now amenable to analysis.

In 1981, Peter left the Wistar Institute to take up his position at Australian National University in Canberra and I joined the Department of Biology at Haverford College, where I have remained ever since, working with multiple generations of superb undergraduates. Since I closed my research laboratory a few years ago, when my late husband's declining health required that I stay home for a few years, I do not have recent experiments to report on in this volume. Instead, I would like to pay homage to some lessons that I learned in the Doherty Lab and that I brought with me to Haverford. I have tried to pass these on to my students as they participated in advanced laboratories and developed their senior research projects. Since many of these young people have pursued their own research careers, the reach of Peter's teaching has extended in an exponential way through these young minds. Here, in no particular order, are some of the important lessons I learned directly from Peter and have tried to share with my students.

- Take the time you need to think very hard before you start an experiment, and pay very careful attention to its design. Read around your topic and talk to everyone you can about what you are doing. Think about the article you hope to write on this topic and ask yourself: "What figure do you hope to make out of this part of the experiment? What should your controls be? What is missing from this design that you should have thought of? What will you learn from this experiment even if it fails, or if the results are not what you hoped they might be?"

- "Bury the corpse" - a direct quote. Halfway through an experiment you realize you have made a mistake. Finish the experiment anyway-you might learn something you did not expect to.

- Remember that the animals you use have sacrificed everything; you owe them your best work.

- Be generous with your time and listen hard when others in the laboratory want to talk about their work. Participate in collaborations whenever you can and be kind but fair in discussions about credit and coauthorship. Always give credit wherever it is due and err on the side of generosity.

- No matter your committee, teaching, and writing obligations, show up in the laboratory each day. It makes a huge difference to everyone to know that you are there, and available, even if it is only for a short time.

- When someone in your laboratory has worked long and hard for a set of results and it is clear that the experiment is finally working, stand with them, celebrate, and encourage the whole laboratory to share in the moment.

- Build a sense of community within your laboratory and your group of collaborators; encourage kindness and cooperation, look out for those who are struggling, and offer encouragement. Protect the members of the laboratory from external political pressures. Be willing to step in as necessary if certain members of the laboratory cause difficulties or if people are not working up to the standard you expect.

Department of Biology, Haverford College, Haverford, Pennsylvania.

(C) Judith Owen, 2019; Published by Mary Ann Liebert, Inc. This Open Access article is distributed under the terms of the Creative Commons Attribution Noncommercial License (http://creativecommons.org/licenses/by-nc/4.0/) which permits any noncommercial use, distribution, and reproduction in any medium, provided the original author(s) and the source are cited. 
- Learn how to communicate effectively about what it is you want to do, and then to tell a compelling story about it. Hone your verbal and written communication skills and take pride in them. Learn to avoid "writing tics." One of Peter's hints has stuck with me: "nothing should be carried out that isn't a coffin."

- Science is a creative enterprise and, as such, is inherently joyful.

- It is possible both to be a scientist and to sustain a rewarding family life.

In closing, I would like to state that it is a particular pleasure to celebrate a senior male scientist who did everything in his power to support young scientists of all genders, at a time when that was far from a universal trait. Peter and Penny modeled for all of us that it was possible to build and sustain a family while attending to the needs of a busy laboratory and these were lessons my husband and I absorbed and tried to pass on to our own students and postdocs. When I entered Peter's laboratory, we had a 9-month-old daughter and our son was born while I was still in the laboratory. Peter was endlessly understanding of my need to leave in the afternoons in time to pick up children from daycare and never lost sight of the fact that working with influenza meant that we often had to come back to the laboratory late at night, after children were safely in bed. However, with hindsight, it is easy to see that there must have been times when he ached for my project to move faster than it did and I remain extraordinarily grateful for his patience. I have tried to pay that quality of patience forward with my young charges.

In conclusion, reflecting on those 3 years, I know just how lucky I was to work with someone who combined brilliance, joy, kindness, and patience in a way that has inspired not just his own laboratory members, but also those whom we ourselves have trained. In gratitude.

\section{Author Disclosure Statement}

No competing financial interests exist.

Address correspondence to: Prof. Judith A. Owen Department of Biology Haverford College Haverford, PA 19041

E-mail: jowen@haverford.edu 